\title{
KOMPETENSI PENYULUH PERTANIAN LAPANGAN (PPL) DALAM DIFUSI INOVASI BUDIDAYA PADI ORGANIK PADA MASYARAKAT PETANI (KASUS DI KELURAHAN FAJAR ESUK, KECAMATAN PRINGSEWU, KABUPATEN PRINGSEWU)
}

(The Extension Worker Competencies on Diffusion of Organic Rice Cultivation Innovation on Farmer Society: A Case in Fajar Esuk Urban Village, Pringsewu Subdistrict, Pringsewu Regency)

Nadia Azzahra, Tubagus Hasanudin, Suarno Sadar

Jurusan Agribisnis, Fakultas Pertanian, Universitas Lampung, Jl. Prof. Dr. Soemantri Brojonegoro No.1 Bandar Lampung 35141, Telp. 082282789981, e-mail: nadiaazzahra2507@ yahoo.com

\begin{abstract}
This study aims to find out the extension worker competencies of organic rice innovation, the level of diffusion of the innovation, and factors related to the diffusion in farmer society in Fajar Esuk Urban Village Pringsewu Subdistrict. The location of this study was chosen purposively in Fajar Esuk Urban Village with 11 respondents. Data of this research were collected in August 2017 with a survey method. The research used descriptive analysis and nonparametric statistic Rank Spearman correlation test. The results of this research showed that the extension worker competencies on diffusion of organic rice cultivation innovation in farmer society is quite competent (middle class). The level of diffusion innovation of organic rice cultivation is in a medium class. Innovation characteristics variable (X2) has a significant correlation with diffusion of organic rice cultivation. However, the extension worker competencies(X1), society support (X3) and farmer's perception about organic rice cultivation (X4) have no significant correlation with diffusion organic rice cultivation innovation in farmer society.
\end{abstract}

Key words :competence, cultivation, diffusion, innovation, organic rice

\section{PENDAHULUAN}

Pembangunan merupakan suatu proses yang perlu berkelanjutan dan dapat berkesinambungan. Pembangunan pertanian yang berhasil dapat diartikan jika terjadi pertumbuhan sektor pertanian yang tinggi dan sekaligus terjadi perubahan ke arah yang lebih baik (Soekartawi 1995). Indonesia adalah negara agraris yang sebagian besar penduduknya hidup dari hasil bercocok tanam, sehingga pertanian merupakan sektor yang memegang peranan penting dalam kesejahteraan kehidupan penduduk Indonesia. Kontribusi sektor pertanian masih relatif lebih besar

Sektor pertanian berperan penting dalam menyediakan bahan pangan bagi seluruh penduduk maupun menyediakan bahan baku bagi industri, dan untuk perdagangan ekspor (Suparta 2010). Hal ini diawali dengan meningkatkan kualitas sumber daya manusia yang baik, dimana setiap individu dalam rumah tangga mendapatkan asupan pangan dalam jumlah yang cukup, aman, dan bergizi secara berkelanjutan yang pada gilirannya akan meningkatkan status kesehatan dan memberikan kesempatan agar setiap individu mencapai potensi maksimumnya.
Keberhasilan pembangunan pertanian dapat dicapai salah satunya dengan pertanian organik. Pertanian organik adalah teknik budidaya pertanian yang mengandalkan bahan-bahan alami tanpa menggunakan bahan-bahan kimia sintetis. Tujuan utama pertanian organik adalah menyediakan produk-produk pertanian, terutama bahan pangan yang aman bagi kesehatan produsen dan konsumennya serta tidak merusak lingkungan. Isu keamanan bahan pangan ini telah melembaga secara internasional yang mensyaratkan jaminan bahwa produk pertanian harus beratribut aman dikonsumsi (food safety attributes), kandungan nutrisi tinggi (nutritional attributes), dan ramah lingkungan (eco-labelling attributes).

Provinsi Lampung menjadi salah satu provinsi di Indonesia yang telah mengembangkan pertanian organik. Salah satu komoditas yang sedang dikembangkan adalah padi organik. Berdasarkan data BPS (2013), produktivitas padi di Kabupaten Pringsewu menempati urutan keempat setelah Lampung Selatan. Berdasarkan keterangan pihak Dinas Perkebunan, Hortikultura, dan Tanaman Pangan Provinsi Lampung, Kecamatan Pringsewu merupakan pusat produksi padi organik dan sebagai daerah pelopor padi organik di Provinsi Lampung. Namun, produksi padi tertinggi terlihat 
pada Kecamatan Pagelaran Utara dan Gadingrejo (BPS Pringsewu 2014), sedangkan di Kecamatan Pringsewu produksi padi masih terbilang rendah.

Rendahnya produksi padi organik di Kecamatan Pringsewu diduga karena sebagian masyarakat kurang memiliki motivasi untuk melakukan budidaya padi organik dan sebagian petani beranggapan bahwa budidaya padi organik secara ekonomi merugikan dibandingkan dengan budidaya padi nonorganik. Selain beberapa hal tersebut,untuk membantu meningkatkan produksi padi organik di Kecamatan Pringsewu, diperlukan penyuluh yang berkompeten di bidangnya. Kompetensi penyuluh pertanian adalah kemampuan atau potensi internal yang ada pada diri penyuluh. Berlo (1960) mengemukakan kompetensi yang harus dimiliki oleh setiap penyuluh mencakup: kemampuan berkomunikasi, sikap di tengah masyarakat, serta kemampuan pengetahuan dan keahlian dalam bidang pertanian. Kompetensi penyuluh yang baik akan mempengaruhi proses difusi inovasi yang terjadi pada msyarakat petani.

Setelah mengetahui pentingnya kompetensi penyuluh dalam difusi inovasi budidaya padi organik, diharapkan terjadi peningkatan produksi padi organik. Berdasarkan uraian tersebut, tujuan penelitian ini adalah untuk mengetahui kompetensi penyuluh dalam difusi inovasi padi organik pada masyarakat petani, mengetahui tingkat difusi inovasi budidaya padi organik pada masyarakat petani, dan untuk mengetahui faktor-faktor yang berhubungan dengan difusi inovasi budidaya padi organik pada masyarakat petani di Kelurahan Fajar Esuk, Kecamatan Pringsewu, Kabupaten Pringsewu.

\section{METODE PENELITIAN}

Penelitian ini menggunakan metode survei. Menurut Singarimbun (1995) metode survey yaitu penelitian yang mengambil sampel menggunakan kuesioner sebagai pengumpul data. Jenis data yang digunakan dalam penelitian ini adalah data primer dan data sekunder. Lokasi penelitian ditentukan secara sengaja (purposive) di Kelurahan Fajar Esuk, Kecamatan Pringsewu dengan pertimbangan bahwa kelurahan tersebut dianggap mewakili daerah dimana petaninya membudidayakan padi organik dan tergabung dalam Kelompok Tani Padi SRI Organik Sejahtera. Responden penelitian adalah petani padi organik di lokasi penelitian sebanyak 11 petani. Sumber data pada penelitian ini berasal dari data primer dan data sekunder. Pengambilan data dilakukan pada bulan Agustus 2017.

Variabel yang diduga berhubungan dengan tingkat difusi inovasi budidaya padi organik pada masyarakat petani (Y) adalah kompetensi penyuluh (X1), sifat inovasi (X2), dukungan masyarakat (X3), dan persepsi petani terhadap budidaya padi organik (X4). Pengukuran beberapa variabel menggunakan teknik skoring (1-3). Data ordinal pada penelitian ini diubah menjadi data interval menggunakan metode MSI (Method Successive Interval).

Metode analisis deskriptif digunakan untuk menjawab tujuan pertama dan kedua, sedangkan uji statistik nonparametrik korelasi Rank Spearman (Siegel 1998) dengan bantuan SPSS versi 17.0 digunakan untuk menjawab tujuan ketiga. Kriteria pengambilan keputusan pada penelitian ini adalah sebagai berikut:

1. Jika nilai signifikansi $\leq \alpha(0,2)$, maka $\mathrm{H}_{0}$ ditolak, $\mathrm{H}_{1}$ diterima., artinya terdapat hubungan antara kedua variabel yang diuji.

2. Jika nilai signifikansi $>\alpha(0,2)$, maka $\mathrm{H}_{0}$ diterima, $\mathrm{H}_{1}$ ditolak, artinya tidak terdapat hubungan antara kedua variabel yang diuji.

\section{HASIL PENELITIAN}

\section{Analisis Difusi Inovasi Budidaya Padi Organik pada Masyarakat Petani di Kelurahan Fajar Esuk}

Difusi Inovasi memiliki makna suatu proses penyebaran serapan ide-ide atau hal-hal yang baru dalam upaya untuk merubah suatu masyarakat, terjadi secara terus menerus dari suatu tempat ke tempat yang lain, dari suatu kurun waktu ke kurun waktu yang berikut, dari suatu bidang tertentu ke bidang yang lainnya kepada sekelompok anggota dari sistem sosial (Rogers,1983). Tingkat difusi inovasi diklasifikasikan dalam 3 (tiga) kelas yaitu, rendah $(13,84-15,62)$, sedang $(15,63-17,41)$, dan tinggi $(17,42-19,17)$. Sebaran difusi inovasi budidaya padi organik dapat dilihat pada Tabel 1 . 
Tabel 1. Difusi inovasi budidaya padi organik pada masyarakat petani

\begin{tabular}{cccc}
\hline Interval skor & Klasifikasi & $\begin{array}{c}\text { Jumlah } \\
\text { (orang) }\end{array}$ & $\begin{array}{c}\text { Persentase } \\
(\%)\end{array}$ \\
\hline $13,84-15,62$ & Rendah & 1 & 9,09 \\
$15,63-17,41$ & Sedang & 9 & 81,82 \\
$17,42-19,17$ & Tinggi & 1 & 9,09 \\
\hline Jumlah & & 11 & 100,00 \\
\hline Rata-rata: 16,99 (sedang) & & \\
\hline
\end{tabular}

Berdasarkan Tabel 1, dapat diketahui bahwa sebagian besar $(81,82 \%)$ tingkat difusi inovasi petani padi organik berada pada klasifikasi sedang, sisanya masing-masing sebesar 9,09 persen berada pada klasifikasi rendah dan tinggi. Tingkat difusi inovasi yang berada pada klasifikasi sedang tersebut karena kurang maksimalnya peran aktif penyuluh untuk memberikan penyuluhan tentang inovasi budidaya padi organik. Selain itu, kurangnya tingkat difusi inovasi pada masyarakat petani juga dikarenakan petani sendirilah yang belum maksimal untuk ikut andil menyebarkan informasi tentang budidaya padi organik kepada petani lainnya, sehingga cakupannya tidak terlalu luas.

Jumlah petani di Kelurahan Fajar Esuk yang menerapkan budidaya padi organik sampai tahun 2017 terus menurun. Menurut responden pada tahun2013jumlah anggota kelompok tani yang menerapkan budidaya padi organik sebanyak 21 petani, namun sampai tahun 2017 hanya 11 orang anggota yang masih menerapkan budidaya padi organik. Penurunan jumlah petani juga mengakibatkan berkurangnya luas lahan yang digunakan untuk budidaya padi organik, dari semula 5 ha menjadi sekitar 2,5- 3 ha saja.

Jangka waktu yang dibutuhkan sebagian besar $(90,91 \%)$ responden petani padi organik di Kelurahan Fajar Esuk untuk memahami inovasi budidaya padi organik yang diberikan adalah 1-2 bulan. Waktu yang dibutuhkan oleh sebagian besar $(90,91 \%)$ responden petani padi organik di Kelurahan Fajar Esuk untuk mengambil keputusan untuk menolak atau menerima inovasi budidaya padi organi adalah 1-2 bulan. Sedangkan waktu yang dibutuhkan seluruh responden petani padi organik di Kelurahan Fajar Esuk untuk menerapkan inovasi budidaya padi organik adalah selama 5-6 bulan. Petani mengaku meski membutuhkan waktu untuk menyesuaikan, tetapi karena selalu mendapat arahan dari berbagai pihak, petani dapat lebih cepat menerima inovasi yang diberikan oleh penyuluh padi organik di Kelurahan Fajar Esuk.

\section{Deskripsi Faktor-Faktor yang Berhubungan Dengan Difusi Inovasi Budidaya Padi Organik pada Masyarakat Petani di Kelurahan Fajar Esuk}

Pada penelitian ini, faktor-faktor yang diduga berhubungan dengan difusi inovasi budidaya padi organik pada masyarakat petani yaitu, kompetensi penyuluh, sifat inovasi, dukungan masyarakat, dan persepsi petani terhadap budidaya. Penjelasan dari analisis faktor-faktor yang diduga berhubungan dengan difusi inovasi budidaya padi organik pada masyarakat petani adalah sebagai berikut.

\section{Kompetensi Penyuluh (X1)}

Kompetensi penyuluh merupakan salah satu atribut individu yang mengakibatkan adanya perbedaan diantara individu di dalam organisasi. Tujuan penggunaan analisis kompetensi penyuluh adalah untuk mengidentifikasi pengetahuan penyuluh tentang inovasi, keterampilan penyuluh dalam penggunaan teknologi informasi dan multimedia, serta kemampuan penyuluh dalam berkomunikasi tentang inovasi.

Skor tertinggi kompetensi penyuluh yaitu 22,50 dan skor terendahnya adalah 15,93. Selanjutnya kompetensi penyuluh diklasifikasikan dalam 3 (tiga) kelas yaitu, kurang kompeten $(15,93-18,12)$, cukup kompeten $(18,13-20,32)$ dan kompeten (20,33-22,50). Sebaran kompetensi penyuluh dapat dilihat pada Tabel 2. Berdasarkan Tabel 2 dapat diketahui bahwa tingkat kompetensi penyuluh dalam difusi inovasi padi organik berada pada klasifikasi cukup kompeten dengan yaitu sebesar $(54,55 \%)$.

Tabel 2. Kompetensi penyuluh dalam difusi inovasi budidaya padi organik pada masyarakat petani

\begin{tabular}{lccc}
\hline Interval skor & Klasifikasi & $\begin{array}{c}\text { Jumlah } \\
\text { (orang) }\end{array}$ & $\begin{array}{c}\text { Persentase } \\
(\%)\end{array}$ \\
\hline $15,93-18,12$ & $\begin{array}{c}\text { Kurang } \\
\text { kompeten } \\
\text { Cukup }\end{array}$ & 4 & 36,36 \\
$18,13-20,32$ & 6 & 54,55 \\
20,33-22,50 & $\begin{array}{c}\text { Kompeten } \\
\text { Kompeten }\end{array}$ & 1 & 9,09 \\
\hline Jumlah & 11 & 100,00 \\
\hline Rata-rata: 19,04 (Cukup Kompeten) & & \\
\hline
\end{tabular}


Inovasi juga dilakukan hingga tahap pascapanen seperti pengemasan, pelabelan, hingga pemasaran padi organik. Sebanyak $(36,36 \%)$ responden menilai kompetensi penyuluh kurang kompeten dan sisanya 9,09 persen menilai bahwa penyuluh sudah kompeten. Hal ini dibuktikan dengan adanya usaha penyuluh dalam memberikan inovasi seperti, pembuatan pestisida nabati dan pupuk organik. Pengetahuan penyuluh padi organik tentang inovasi budidaya padi organik sudah cukup memadai. Hal tersebut dibuktikan dengan usaha penyuluh memberikan inovasi seperti, pembuatanpestisida nabati dan pupuk organik. Inovasi juga dilakukan hingga tahap pascapanen seperti pengemasan, pelabelan, hingga pemasaran padi organik. Kelompok Tani Padi Sri Organik Sejahtera tidak hanya menghasilkan beras biasa tetapi juga beras merah. Inovasi yang coba dilakukan tidak hanya itu, Kelompok Tani Padi Sri Organik Sejahtera juga sudah mendapat sertifikat Inavis. Sertifikat tersebut merupakan sertifikat yang khusus dikeluarkan untuk produk organik dari Lembaga Setrifikasi Organik Indonesia.

Kompetensi penyuluh juga terlihat dalam penguasaan penggunaan teknologi informasi dan multimedia. Teknologi informasi yang sering digunakan seperti, laptop dan LCD saat mengadakan penyuluhan atau sosialisasi dalam ruangan, serta penggunaan multimedia untuk membuat selebaran materi dalam bentuk leaflet. Penggunaan teknologi informasi dan multimedia memang tidak selalu dilakukan. Penyuluh mengaku lebih sering menggunakan metode demplot cara saat memberikan informasi inovasi budidaya padi organik. Hal tersebut dilakukan agar petani lebih yakin dengan keberhasilan inovasi yang diberikan.

Kemampuan penyuluh padi organik dalam berkomunikasi dinilai responden petani sudah cukup baik. Petani mengaku cukup puas terhadap cara penyampaian informasi inovasi budidaya padi organik yang dilakukan oleh penyuluh. Penyuluh mengaku tidak ada kendala dalam berkomunikasi kepada petani, hal ini karena penyuluh sudah mengetahui karakteristik petani binaannya (bahasa mayoritas Jawa). Penyuluh mendapatkan informasi tentang inovasi budidaya padi organik dalam bentuk bahan/materi penyuluhan melalui berbagai sumber, seperti Dinas Pertanian Provinsi, Dinas Pertanian Kabupaten dan sumber lainnya. Menurut penyuluh, meski tidak semua petani menanam padi organik, petani di wilayah binaannya termasuk ke dalam petani yang mudah diarahkan.
Saat proses penyampaian inovasi, penyuluh menggunakan berbagai media yang memungkinkan seperti, media cetak maupun elektronik. Hal tersebut dipilih karena petani cenderung cepat bosan jika hanya diberikan materi saja. Jika sudah demikian, Penyuluh biasanya akan mencari metode lain yang lebih disukai seperti metode demonstrasi cara (Demcar). Menurut penyuluh, respon petani terhadap proses penyampaian informasi tentang budidaya padi organik memang berbeda-beda, tetapi untuk mempermudah dan mempercepat proses penyampaian inovasi padi organik, penyuluh dibantu oleh anggota kelompok tani lainnya yang sudah lebih mengerti tentang inovasi budidaya padi organik.

Tujuan penggunaan faktor kompetensi penyuluh pada penelitian ini adalah untuk mengidentifikasi pengetahuan penyuluh tentang inovasi, keterampilan penyuluh dalam penggunaan teknologi informasi dan multimedia, serta kemampuan penyuluh dalam berkomunikasi tentang inovasi.Skor yang merupakan data ordinal pada penelitian ini diubah menjadi data interval menggunakan MSI, sehingga diperoleh skor tertinggi kompetensi penyuluh yaitu 22,50 dan skor terendahnya adalah 15,93 .

Tingkat kompetensi penyuluh dalam difusi inovasi padi organik berada pada klasifikasi cukup kompeten dengan rata-rata skor 19,04. Sebagian besar $(54,55 \%)$ responden petani organik menyatakan bahwa kompetensi yang dimiliki penyuluh dalam difusi inovasi budidaya padi organik sudah cukup kompeten, 36,36 persen responden menilai kompetensi penyuluh kurang kompeten dan sisanya 9,09 persen menilai bahwa penyuluh sudah kompeten.

\section{Sifat Inovasi (X2)}

Sifat inovasi pada penelitian ini merupakan ciri-ciri yang dimiliki oleh suatu inovasi dengan menggunakan lima indikator, yaitu: 1) keuntungan relatif, 2) keserasian, 3) kerumitan, 4) dapat diuji coba, dan 5) dapat di obeservasi. Ada15 pertanyaan yang diajukan dalam penelitian ini. Skor yang merupakan data ordinal pada penelitian ini diubah menjadi data interval menggunakan MSI, sehingga diperoleh skor tertinggi sifat inovasi yaitu 34,52 dan skor terendahnya adalah 25,93. Berdasarkan Tabel 3 dapat dilihat sebaran sifat inovasi budidaya padi organik pada masyarakat petani. Sifat inovasi diklasifikasikan dalam 3 (tiga) kelas yaitu, kurang mudah dan kurang menguntungkan $(25,93-28,79)$, 
cukup mudah dan cukup menguntungkan $(28,80$ $31,66)$ dan mudah dan menguntungkan $(31,67-$ $34,52)$.

Menurut beberapa responden sifat inovasi budidaya padi organik menguntungkan. Berdasarkan keterangan dari penyuluh, menguntungkan atau tidaknya budidaya padi organik tergantung pada orientasi petani. Jika orientasinya untuk meningkatkan produktivitas gabah, maka petani akan lebih memilih untuk menerapkan budidaya padi nonorganik. Namun jika orientasinya lebih kepada kesadaran akan kebutuhan pangan yang sehat dan harga jual yang lebih tinggi, maka petani akan lebih memilih untuk menerapkan budidaya padi organik.

Penyuluh menjelaskan, perawatan pada budidaya padi organik lebih mudah dibandingkan padi nonorganik. Hal ini karena sarana produksi pada budidaya padi organik dapat dibuat sendiri oleh petani. Responden berpendapat bahwa dengan adanya inovasi budidaya padi organik tidak hanya memberikan manfaat terhadap kegiatan budidaya, tetapi juga menguntungkan karena mampu menjaga lingkungan dan menambah pendapatan petani. Pada indikator sifat inovasi kesesuaian (kompatibilitas), masyarakat petani mengaku inovasi budidaya padi organik yang ada didaerah mereka sudah sesuai. Tidak hanya sesuai dengan kondisi alamnya, tetapi juga petani dapat menerima inovasi budidaya padi organik sesuai dengan kebutuhan petani.

Pada Indikator sifat inovasi kerumitan (kompleksitas), masyarakat petani mengaku bahwa tingkat kerumitan inovasi budidaya padi organik adalah cukup rumit. Awalnya masyarakat petani cukup sulit untuk menerapkan atau mengaplikasikan inovasi budidaya padi organik.

Tabel 3. Sifat inovasi budidaya padi organik pada masyarakat petani

\begin{tabular}{lccc}
\hline Interval skor & Klasifikasi & $\begin{array}{c}\text { Jumlah } \\
\text { (orang) }\end{array}$ & $\begin{array}{c}\text { Persentase } \\
(\%)\end{array}$ \\
\hline $25,93-28,79$ & $\begin{array}{c}\text { Kurang mudah } \\
\text { dan kurang } \\
\text { menguntungkan }\end{array}$ & 5 & 45,45 \\
28,80-31,66 & $\begin{array}{c}\text { Cukup mudah dan } \\
\text { cukup } \\
\text { menguntungkan } \\
\text { Mudah dan }\end{array}$ & 4 & 36,37 \\
Jumlah & 2 & 18,18 \\
\hline Menguntungkan & 11 & 100,00 \\
\hline
\end{tabular}

Rata-rata: 28,88 (Cukup Mudah dan Cukup

Memungkinkan)
Hal tersebut karena petani merasa ragu apakah hasil produksi padi akan lebih baik jika tidak menggunakan pupuk kimia seperti biasanya. Petani juga sempat merasa kesulitan saat harus memenuhi kebutuhan pupuk organik dan air yang bebas dari kontaminasi bahan kimia.

Pada Indikator sifat inovasi dapat diuji coba (triabilitas), masyarakat petani mengaku bahwa inovasi budidaya padi organik cukup dapat diuji coba. Hal tersebut karena masyarakat petani mampu menerapkan inovasi budidaya padi organik meski membutuhkan waktu dan usaha yang lebih banyak.Pada Indikator sifat inovasi dapat diobservasi (observabilitas), masyarakat petani mengaku inovasi yang ada cukup dapat diobservasi. Menurut petani, observasi juga cukup mudah dilakukan meski intensitasnya lebih sering dibanding saat budidaya padi nonorganik. Masyarakat petani juga merasakan manfaat membudidayakan padi secara organik tidak hanya bagi kesehatan, tetapi manfaat bagi lingkungan dan juga pendapatan karena harga jual yang lebih tinggi.

\section{Dukungan Masyarakat}

Dukungan masyarakat pada penelitian ini adalah bentuk dukungan yang diberikan kepada seseorang dengan hubungan sosialnya dengan orang lain dan dorongan yang diberikan oleh sekumpulan orang yang tinggal di satu wilayah. Dukungan masyarakat atau sosial dianalisis berdasarkan empat indikator, yaitu dukungan informasi, dukungan emosional, dukungan instrumental, dan dukungan appraisal atau penilaian.

Skor yang merupakan data ordinal diubah menjadi data interval menggunakan MSI. Skor tertinggi sifat inovasi yaitu 30,52 dan skor terendah adalah 22,48 . Dukungan masyarakat diklasifikasikan dalam 3 (tiga) kelas yaitu, rendah $(22,48-25,16)$, sedang $(25,17-27,85)$ dan tinggi $(27,86-30,52)$. Sebaran dukungan masyarakat dalam difusi inovasi budidaya padi organik pada masyarakat petani dapat dilihat pada Tabel 4.

Pada Tabel 4 tersebut dapat diketahui bahwa dukungan masyarakat terhadap inovasi budidaya padi organik berada pada klasifikasi sedang dengan rata-rata skor 25,30. Sebanyak 7 responden $(63,64 \%)$ petani organik memberikan dukungan dengan tingkat dukungan yang rendah, sebesar 27,27 persen responden memberikan dukungan yang sedang, sisanya sebesar 9,09 persen. 
Tabel 4. Dukungan masyarakat dalam difusi inovasi budidaya padi organik pada masyarakat petani

\begin{tabular}{lccc}
\hline Interval Skor & Klasifikasi & $\begin{array}{c}\text { Jumlah } \\
\text { (orang) }\end{array}$ & $\begin{array}{c}\text { Persentase } \\
(\%)\end{array}$ \\
\hline $22,48-25,16$ & Rendah & 7 & 63,64 \\
$25,17-27,85$ & Sedang & 3 & 27,27 \\
$27,86-30,52$ & Tinggi & 1 & 9,09 \\
\hline Jumlah & & 11 & 100,00 \\
\hline Rata-rata: 25,30 (sedang) & & \\
\hline
\end{tabular}

Menurut sebagian besar responden, masyarakat sekitar memberikan dukungan dalam bentuk informasi walaupun hanya sedikit. Masyarakat juga cukup terbuka dalam menyampaikan informasi mengenai inovasi budidaya padi organik. Dukungan emosional masyarakat sekitar terlihat dari sedikitnya antusias masyarakat dalam menerima informasi mengenai inovasi budidaya padi organik. Hanya sebagian masyarakat petani yang berpartisipasi dalam penerapan inovasi budidaya padi organik. Meski demikian, masyarakat juga cukup memiliki kepercayaan terhadap keberhasilan inovasi budidaya padi organik.

Dukungan instrumental dari masyarakat tidak terlalu banyak terlihat. Menurut penyuluh, hanya sedikit anggota masyarakat petani yang memberikan dukungan yang nyata dalam bentuk tenaga, waktu, dan materil. Dukungan apprasial atau penilaian dari masyarakat terlihat dari adanya saran atau masukan dalam setiap inovasi budidaya padi organik yang disampaikan.

\section{Persepsi Petani terhadap Budidaya}

Persepsi petani bertujuan untuk melihat kesadaran seseorang tentang keadaan lingkungannya terhadap inovasi budidaya padi organik. Persepsi petani pada penelitian bertujuan untuk melihat bagaimana seseorang menjadi sadar tentang keadaan lingkungannya terhadap inovasi budidaya padi organik. Sebaran persepsi petani dapat dilihat pada Tabel 5.

Tabel 5. Persepsi petani terhadap difusi inovasi budidaya padi organik

\begin{tabular}{cccc}
\hline Interval Skor & Klasifikasi & $\begin{array}{c}\text { Jumlah } \\
\text { (orang) }\end{array}$ & $\begin{array}{c}\text { Persentase } \\
(\%)\end{array}$ \\
\hline $7,80-8,90$ & Kurang baik & 1 & 9,09 \\
$8,91-10,01$ & Cukup baik & 4 & 36,36 \\
$10,02-11,10$ & Baik & 6 & 54,55 \\
\hline Jumlah & 11 & 100,00 \\
\hline Rata-rata: 10,13 (cukup baik) & & \\
\hline
\end{tabular}

Skor yang merupakan data ordinal pada penelitian ini diubah menjadi data interval menggunakan MSI, sehingga diperoleh skor tertinggi persepsi petani yaitu 11,10 dan skor terendahnya adalah 7,80. Persepsi petani terhadap budidaya diklasifikasikan dalam 3 (tiga) kelas yaitu, kurang baik $(7,80-8,90)$, cukup baik $(8,91-10,01)$, dan baik $(10,02-11,10)$.

Pada Tabel 5 tersebut, dapat diketahui bahwa persepsi petani terhadap inovasi budidaya padi organik berada pada klasifikasi cukup baik dengan rata-rata skor 10,13. Sebagian besar $(54,55 \%)$ responden petani organik memiliki persepsi yang baik, sedangkan 36,36 persen responden memiliki persepsi yang cukup baik, sisanya 9,09 persen responden memiliki persepsi kurang baik terhadap inovasi budidaya padi organik.Persepsi petani tentang inovasi budidaya padi organik pada umumnya cukup baik. Petani menyatakan bahwa budidaya padi organik sebenarnya tidak jauh berbeda dengan budidaya padi nonorganik.

Meskipun cukup mudah diterapkan, namun terkadang ketersedian pupuk organik, pestisida organik, lahan, dan air menjadi kendala. Beberapa petani yang bertahan membudidayakan padi organik mengaku mendapat keuntungan yang lebih baik. Manfaat yang dirasakan tidak hanya karena harga jual padi organik yang lebih tinggi, tetapi budidaya organik juga dianggap baik bagi kesehatan dan ramah lingkungan.

\section{Pengujian Hipotesis}

Analisis hubungan antara variabel X (faktor-faktor yang berhubungan dengan difusi inovasi) dengan variabel Y (tingkat difusi inovasi budidaya padi organik) dalam penelitian ini menggunakan statistik nonparametrik uji korelasi Rank Spearman dengan bantuan SPSS 17.0. Hasil pengujian disajikan pada Tabel 6 .

Tabel 6. Hasil pengujian statistik variabel $\mathrm{X}$ dan variabel Y

\begin{tabular}{|c|c|c|c|c|}
\hline No. & Variabel X & $\begin{array}{c}\text { Variabel } \\
\text { Y }\end{array}$ & $\begin{array}{c}\text { Koef. } \\
\text { korelasi }\left(r_{s}\right)\end{array}$ & $\begin{array}{c}\text { Sig. } \\
\text { (1-tailed) }\end{array}$ \\
\hline 1. & $\begin{array}{l}\text { Kompetensi } \\
\text { penyuluh }\end{array}$ & Tingkat & $-0,319 *$ & 0,169 \\
\hline 2. & Sifat inovasi & difusi & $0,553 *$ & 0,039 \\
\hline 3. & $\begin{array}{l}\text { Dukungan } \\
\text { masyarakat }\end{array}$ & $\begin{array}{l}\text { inovasi } \\
\text { budidaya }\end{array}$ & $0,417 *$ & 0,101 \\
\hline 4. & $\begin{array}{l}\text { Persepsi petani } \\
\text { tentang budidaya } \\
\text { padi organik }\end{array}$ & $\begin{array}{l}\text { padi } \\
\text { organik }\end{array}$ & $0,031^{\text {tn }}$ & 0,464 \\
\hline
\end{tabular}


Hasil pengujian statistik tersebut variabel yaitu, kompetensi penyuluh (X1), dukungan masyarakat (X3), dan persepsi petani tentang budidaya padi organik (X4) tidak memiliki hubungan yang nyata dengan tingkat difusi inovasi budidaya padi organik pada masyarakat petani menunjukkan bahwa variabel sifat inovasi (X2) memiliki hubungan yang signifikan terhadap tingkat difusi inovasi budidaya padi organik pada taraf kepercayaan $80 \%$. Berdasarkan hasil uji statistik yang telah dilakukan antara sifat inovasi (X2) dengan tingkat difusi inovasi budidaya padi organik (Y), diperoleh nilai koefisien korelasi rank spearman $\left(\mathrm{r}_{\mathrm{s}}\right)$ sebesar 0,553 . Hal ini menunjukkan bahwa hubungan antara sifat inovasi (X2) dengan tingkat difusi inovasi budidaya padi organik (Y) ditentukan sebesar 55,3\%. Nilai signifikansi sebesar 0,039 lebih kecil dari $\alpha(0,2)$ pada taraf kepercayaan $80 \%$, maka dapat diambil keputusan untuk menerima $\mathrm{H}_{1}$, artinya terdapat hubungan yang nyata antara sifat inovasi dengan tingkat difusi inovasi budidaya padi organik pada masyarakat petani.

Sifat inovasi berhubungan dengan proses difusi inovasi yang terjadi pada masyarakat petani karena, semakin mudah dan menguntungkan suatu inovasi budidaya padi organik, maka proses penyebaran inovasi akan terjadi dengan cepat. Sebaliknya, jika suatu inovasi memiliki sifat yang sulit dan tidak menguntungkan bagi petani, maka akan mempengaruhi kecepatan difusi inovasi. Inovasi memang sangat diperlukan untuk membantu keberhasilan pembangunan pertanian, terutama usaha budidaya padi organik. Hal tersebut dikuatkan dengan pendapat Hasanuddin (2005) di dalam jurnalnya yang menyebutkan bahwa keberhasilan pembangunan pertanian bukan hanya karena peran pemerintah, tetapi peran berjuta-juta petani yang menerapkan inovasiinovasi dalam kegiatan usahatani. Dengan demikian, perlu inovasi dalam budidaya padi organik bersifat mudah dan menguntungkan untuk diterapkan.

Kompetensi penyuluh yang masuk dalam klasifikasi cukup kompeten nyatanya belum mampu memberikan kontribusi yang lebih dalam proses difusi inovasi budidaya padi organik. Dukungan masyarakat juga dirasa belum maksimal dalam membantu proses difusi inovasi di Kelurahan Fajar Esuk. Persepsi petani tidak mempengaruhi proses difusi inovasi budidaya padi organik pada masyarakat petani. Meskipun persepsi petani pada penelitian ini masuk dalam klasifikasi cukup baik, nyatanya tidak berpengaruh terhadap proses difusi inovasi budidaya padi organik pada masyarakat petani.

\section{KESIMPULAN}

Berdasarkan hasil penelitian diperoleh kesimpulan sebagai berikut: Kompetensi penyuluh dalam difusi inovasi budidaya padi organik pada masyarakat petani di Kelurahan Fajar Esuk, Kecamatan Pringsewu, Kabupaten Pringsewu masuk dalam klasifikasi cukup kompeten.Tingkat difusi inovasi budidaya padi organik pada masyarakat petani di Kelurahan Fajar Esuk, Kecamatan Pringsewu, Kabupaten Pringsewu masuk dalam klasifikasi sedang.Faktor yang berhubungan dengan difusi inovasi budidaya padi organik pada masyarakat petani adalah, kompetensi penyuluh (X1), sifat inovasi (X2), dukungan masyarakat (X3) sedangkan variabel persepsi petani terhadap budidaya (X4) tidak memiliki hubungan yang nyata dengan tingkatdifusi inovasi budidaya padi organik pada masyarakat petani di Kelurahan Fajar Esuk, Kecamatan Pringsewu, Kabupaten Pringsewu.

\section{DAFTAR PUSTAKA}

Asiah N. 2010. Persepsi petani terhadap padi organik di Kecamatan Pagelaran Kabupaten Pringsewu. Skripsi. Universitas Lampung. Bandar Lampung.

Badan Pusat Statistik. 2013. Lampung Dalam Angka 2013. Badan Pusat Statistik Provinsi Lampung. Bandar Lampung.

Berlo DK. 1960. The Process of Communication: An Introduction to Theoryand Practice. Holt, Rinehart and Winston. New York.

Dinas Pertanian. 2014. Data Produksi Padi Organik. Dinas Pertanian Provinsi Lampung. Bandar Lampung.

Hasanuddin T. 2005. Adopsi inovasi dalam kegiatan usahatani padi pada beberapa spesifik sosiobudaya petani di Provinsi Lampung. Jurnal AGRIJATI 1 (1) Desember 2005. Fakultas Pertanian Universitas Lampung. Lampung.

Rogers EM. 1983. Difussions of Innovations. London.

Siegel S. 1986. Statistik Nonparametrik. PT Gramedia Pustaka Utama. Jakarta.

Soekartawi. 1995. Analisis Usaha Tani. Universitas Jakarta Press.Jakarta.

Suparta N. 2010. Memantapkan Strategi Pengelolaan Pertanian. Pustaka Nayottama. Denpasar. 
Irsa R, Nikmatullah D, dan Rangga KK. 2018. Persepsi petani dan efektivitas kelompok tani dalam Program Upsus Pajale di Kecamatan Banjar Baru Kabupaten Tulang Bawang. JIIA:6(1):1-8. http:// jurnal.fp.unila.ac.id/index.php/JIA/article/ view/2490. [5 Mei 2018].

Sari J, Nurmayasari I, dan Yanfika H. 2015 Persepsi petani terhadap kinerja penyuluh dalam pengembangan padi organik di
Kecamatan Pagelaran Kabupaten Pringsewu. JIIA: 3(4)432-439. http://jur nal.fp.unila.ac.id/index.php/JIA/article/vie w /1094/999. [5 Mei 2018].

Nurjayanti A, Effendi I, dan Nurmaysari I. 2016. Pendapatan dan manfaat usahatani padi organik di Kabupaten Pringsewu. JIIA: 4(2). http://jurnal.fp.unila.ac.id/inde x.php/JIA/article/view/1229/1126. [5 Mei 2018]. 